\title{
Involvement of a Quorum Sensing Signal Molecule in the Extracellular Amylase Activity of the Thermophilic Anoxybacillus amylolyticus
}

\author{
Annabella Tramice, Adele Cutignano $\mathbb{C}^{0}$, Annalaura Iodice, Annarita Poli $\mathbb{C}$, Ilaria Finore $\mathbb{C}$ \\ and Giuseppina Tommonaro *(i) \\ National Research Council of Italy, Institute of Biomolecular Chemistry, 34- 80078 Pozzuoli, Italy; \\ atramice@icb.cnr.it (A.T.); acutignano@icb.cnr.it (A.C.); annalaura94@live.com (A.I.); apoli@icb.cnr.it (A.P.); \\ ilaria.finore@icb.cnr.it (I.F.) \\ * Correspondence: gtommonaro@icb.cnr.it; Tel.: +39-0818675029
}

\section{check for} updates

Citation: Tramice, A.; Cutignano, A.; Iodice, A.; Poli, A.; Finore, I.; Tommonaro, G. Involvement of a Quorum Sensing Signal Molecule in the Extracellular Amylase Activity of the Thermophilic Anoxybacillus amylolyticus. Microorganisms 2021, 9, 819. https://doi.org/10.3390/ microorganisms 9040819

Academic Editor: Ricardo Amils

Received: 1 March 2021

Accepted: 10 April 2021

Published: 13 April 2021

Publisher's Note: MDPI stays neutral with regard to jurisdictional claims in published maps and institutional affiliations.

Copyright: (c) 2021 by the authors. Licensee MDPI, Basel, Switzerland. This article is an open access article distributed under the terms and conditions of the Creative Commons Attribution (CC BY) license (https:/ / creativecommons.org/licenses/by/ $4.0 /)$.

\begin{abstract}
Anoxybacillus amylolyticus is a moderate thermophilic microorganism producing an exopolysaccharide and an extracellular $\alpha$-amylase able to hydrolyze starch. The synthesis of several biomolecules is often regulated by a quorum sensing (QS) mechanism, a chemical cell-to-cell communication based on the production and diffusion of small molecules named "autoinducers", most of which belonging to the $N$-acyl homoserine lactones' (AHLs) family. There are few reports about this mechanism in extremophiles, in particular thermophiles. Here, we report the identification of a signal molecule, the $N$-butanoyl-homoserine lactone (C4-HSL), from the milieu of $A$. amylolyticus. Moreover, investigations performed by supplementing a known QS inhibitor, trans-cinnamaldehyde, or exogenous C4-HSL in the growth medium of A. amylolyticus suggested the involvement of QS signaling in the modulation of extracellular $\alpha$-amylase activity. The data showed that the presence of the QS inhibitor trans-cinnamaldehyde in the medium decreased amylolytic activity, which, conversely, was increased by the effect of exogenous C4-HSL. Overall, these results represent the first evidence of the production of AHLs in thermophilic microorganisms, which could be responsible for a communication system regulating thermostable $\alpha$-amylase activity.
\end{abstract}

Keywords: Anoxybacillus amylolyticus; extremophiles; quorum sensing; $\alpha$-amylase; trans-cinnamaldehyde; UPLC/MRM

\section{Introduction}

Anoxybacillus amylolyticus (strain MR3C ${ }^{\mathrm{T}}=$ ATCC BAA- $872^{\mathrm{T}}$ ) is a moderate thermophilic Gram-positive rod and facultative anaerobe. Exhibiting optimum growth temperature at $61{ }^{\circ} \mathrm{C}$, it is able to grow between 45 and $65^{\circ} \mathrm{C}$ and at $\mathrm{pH}$ 5.6. It is able to produce an exopolysaccharide and to synthesize an extracellular constitutive amylolytic activity which digests starch. The maximum amylolytic activity is expressed in the stationary growth phase [1]. Amylases belong to families of enzymes used in several biotechnological and industrial processes (e.g., starch processing, sugar production) [2,3], and in textile and pharmaceutical industries [4]. They can be obtained from different sources, including plants, animals, and microorganisms, although microbial enzymes are generally preferred, due to their advantages such as efficient production, stability, and cost-effectiveness [5,6]. The ability of $A$. amylolyticus to produce extracellular amylase enzymes is related to its role in hydrolyzing complex organic matter and generating nutrients. Purified extracellular $\alpha$-amylase from $A$. amylolyticus showed a molecular weight of about $60 \mathrm{KDa}$, as confirmed by gel filtration chromatography an SDS-PAGE; the latter additionally suggested a single polypeptide chain structure [7]. Several bacterial species were disclosed to have a quorum sensing mechanism, acting at gene expression level, to regulate a wide variety of physiological activities, e.g., motility, biofilm development, growth inhibition, virulence 
expression, and plasmid conjugation [8]. At the basis of QS there is synthesis by these microorganisms and the subsequent release in their extracellular milieu of small diffusible compounds, named auto-inducers (AIs). The best known QS mechanism relies on the synthesis of $N$-acyl-homoserine lactones (AHLs) (AI-1 QS), but other QS systems based on different signal molecules (4,5-Dihydroxy-2,3-pentanedione (DPD), autoinducer-1 (CAI-1), diketopiperazines (DKPs)) were found among various microorganisms $[9,10]$. Despite numerous reports on well-characterized cell-to-cell communication in a wide variety of microorganisms, QS is still poorly explored in extremophiles, thus requiring further investigation. In fact, in extremophiles QS could also play a key role in the production of extracellular metabolites (such as enzymes, exopolysaccharides, and lipids) that are attractive for many biotechnological applications in different fields (pharmacology, ecology, molecular biology, and medicine) [11-13].

In this paper, we report the detection of a QS system based on $N$-butanoyl-homoserine lactone (C4-HSL) in the extremophilic microorganism A. amylolyticus. Moreover, the results on the use of trans-cinnamaldehyde (CIN), a known inhibitor of QS [14], and of C4-HSL supplementation during the microbial growth on the extracellular amylolytic activity of A. amylolyticus are discussed.

\section{Materials and Methods}

\subsection{Chemicals}

$\mathrm{N}$-butanoyl-(C4-HSL), $\mathrm{N}$-hexanoyl-(C6-HSL), $\mathrm{N}$-decanoyl-(C-10-HSL), $\mathrm{N}$-dodecanoyl(C12-HSL), N-3-oxobutyryl-(3-oxo-C4-HSL), N-3-oxohexanoyl-(3-oxo-C6-HSL), N-3-oxodecanoyl-(3-oxo-C10-HSL), N-3-oxotridecanoyl-(3-oxo-C13-HSL), N-3-hydroxyhexanoyl-(3OH-C6-HSL), N-3-hydroxyoctanoyl-(3-OH-C8-HSL), N-3-hydroxydecanoyl-(3-OH-C10HSL) homoserine lactone, and trans-cinnamaldehyde were purchased from Sigma-Aldrich, Milano, Italy. LC-MS grade acetonitrile (ACN) was purchased from Merck (Darmstadt, Germany). Water for LC-MS analysis was obtained by a milliQ apparatus (Millipore, Milano, Italy). Standard stock solutions for quantitative analyses were prepared by dissolving C4-HSL in methanol (MeOH) at $100 \mu \mathrm{g} \mathrm{mL}{ }^{-1}$, stored at $-20^{\circ} \mathrm{C}$. Calibration solutions were prepared by diluting the stock solution to the desired concentration $(0.2,1,5,20$, and $200 \mathrm{ng} \mathrm{mL}^{-1}$ ) with $\mathrm{MeOH}$. Merck company (Darmstadt, Germany) furnished silica gel plates for thin layer chromatography (TLC). Compounds on TLC plates were visualized by charring with $\alpha$-naphthol reagent. The TLC solvent system EtOAc/AcOH/2propanol $/ \mathrm{HCOOH} / \mathrm{H}_{2} \mathrm{O}(25: 10: 5: 1: 15 \mathrm{v} / \mathrm{v})$ was used for the visualization of oligosaccharide mixtures of up to six units. Protein concentration was determined by the method of Bradford [15], using bovine serum albumin as standard. Chemical determination of reducing sugar amount was made by the Bernfeld method (3,5 dinitrosalicylic acid, DNS assay) [16], using a glucose-based calibration curve.

\subsection{A. amylolyticus Cultivation}

A. amylolyticus (strain MR3C $\mathrm{C}^{\mathrm{T}}=\mathrm{ATCC} \mathrm{BAA}-872^{\mathrm{T}}$ ) was grown in $\mathrm{Y}_{\mathrm{N}}$ DSM medium containing the following components: yeast extract $0.6 \% w / v, \mathrm{NaCl} 0.6 \% w / v$, and Agar $1.8 \% w / v$ (for plate preparation) at $60{ }^{\circ} \mathrm{C}$. The $\mathrm{pH}$ of the medium was adjusted at 5.6 by using $0.2 \mathrm{M} \mathrm{HCl} \mathrm{[1].} \mathrm{C4-HSL} \mathrm{standard} \mathrm{was} \mathrm{added} \mathrm{to} \mathrm{the} \mathrm{medium} \mathrm{at} \mathrm{a} \mathrm{concentration} \mathrm{of} 10$ $\mu \mathrm{M}$, and CIN was added to the medium to give final concentrations of 1 and $3 \mathrm{mg} \mathrm{mL}^{-1}$ (7.5 and $22 \mathrm{mM}$, respectively). Growths were carried out for $24 \mathrm{~h}$ and monitored both by evaluating their optical density (O.D., $A_{540 \mathrm{~nm}}$ ) and by observation at phase-contrast microscopy (Zeiss). Moreover, cell viability was checked by means of a serial dilution plating method.

\subsection{Extraction of Spent Medium of A. amylolyticus}

Spent medium $(100 \mathrm{~mL})$ from stationary phase cultures of A. amylolyticus was centrifuged at $13,848 \mathrm{~g}$ for $40 \mathrm{~min}$. Pellets were stored at $-20^{\circ} \mathrm{C}$ for further investigation, while supernatants were extracted with ethyl acetate (1:1 $v / v$; twice) and next dried in vacuum 
at $\mathrm{T}<40^{\circ} \mathrm{C}$. The obtained extract was dissolved with methanol to a final concentration of $0.6 \mathrm{mg} \mathrm{mL} \mathrm{m}^{-1}$ and directly tested for the detection of QS signal molecules by means of TLC-overlay assay or diluted 1:10 for LC-MS/MS analysis.

\subsection{Identification of Autoinducer}

\subsubsection{TLC-Overlay Assay}

Supernatant extract and standards (3-oxo-C6-HSL $10 \mu \mathrm{M}$ and 3-oxo-C10-HSL $400 \mu \mathrm{M}$ ) were applied to RP-C18 thin-layer chromatography (TLC) plates $(20 \times 20 \mathrm{~cm}$; VWR International), and developed by using as mobile phase $60 \%(v / v)$ aqueous methanol. The TLC plates were overlaid with $100 \mathrm{~mL}$ of AGTN [17] soft agar $(0.5 \% w / v)$ supplemented with $0.5 \%$ glucose, $40 \mu \mathrm{g} \mathrm{mL}^{-1} \mathrm{X}$-Gal (5-bromo-4-chloro-3-indolyl-beta-D-galactopyranoside), antibiotics (streptomycin, $50 \mu \mathrm{g} \mathrm{mL}^{-1}$ and tetracycline, $4 \mu \mathrm{g} \mathrm{mL}^{-1}$ ), and the biosensor Agrobacterium tumefaciens NTL4 (pCF218; pCF372) able to detect AHLs with medium chain lengths [18]. The TLC plates were kept in a sterile container and incubated at $30{ }^{\circ} \mathrm{C}$ for $24-48 \mathrm{~h}$.

\subsubsection{LC-MS/MS Analysis}

LC-MS analyses were performed according to Abbamondi et al., 2016 [11], with slight modifications. Briefly, chromatographic runs were acquired on an Acquity UPLC System (Waters, Milford, MA, USA) coupled to a 3200 API Triple Quadrupole mass spectrometer (Sciex, Foster City, CA, USA) with aTurbo VTM interface equipped with a turbo ion spray probe used in positive ion mode and on a Acquity UPLC BEH C 18 column $(100 \times 2.1 \mathrm{~mm}$, i.d. $1.7 \mu \mathrm{m}$, Waters, Milford, MA, USA). A water/ACN $(9: 1, v / v)$ mixture was used as eluent $\mathrm{A}$, and $\mathrm{ACN}(100 \%)$ as eluent $\mathrm{B}$. A linear gradient profile was programmed from $100 \%$ A to $100 \%$ B in $1.0 \mathrm{~min}$ and remained constant over $3.0 \mathrm{~min}$, followed by a re-equilibration step of $5 \mathrm{~min}$. Separations were performed at a temperature of $60^{\circ} \mathrm{C}$, using a flow rate of $0.7 \mathrm{~mL} \mathrm{~min}^{-1}$ and an injection volume of $2 \mu \mathrm{l}$.

A multiple reaction monitoring (MRM) experiment was used to collect data, by setting the following source parameters: curtain gas $\left(\mathrm{N}_{2}\right)$ : 20 psi; ion source gas (GS1): 55 psi; turbogas (GS2): $70 \mathrm{psi}$; desolvation temperature: $550{ }^{\circ} \mathrm{C}$; collision activated dissociation gas (CAD): 4 a.u.; and ion spray voltage: $5500 \mathrm{~V}$. The ions monitored in Q1 included the parent AHL $[\mathrm{M}+\mathrm{H}]^{+}$ion, while in Q3 the lactone moiety at $m / z 102$ was monitored. Analyst software (version 1.6.2; SCIEX) was used for the data acquisition and analysis.

\subsection{A. amylolyticus $\alpha$-amylase Assay}

Extracellular $\alpha$-amylase activity was recovered from the stationary $24 \mathrm{~h}$ bacterial growths by centrifugation at $8309 \mathrm{~g}$ for $30 \mathrm{~min}$ and at room temperature. The cell-free supernatant was concentrated by ultrafiltration (Amicon system) on a Millipore Ultrafiltration membrane with a $30 \mathrm{kDa}$ cut-off. Enzymatic activity was recovered in the retentate solution; it was tested for its protein content [15] and $\alpha$-amylase presence [16]. The $\alpha$-amylase activity was assayed referring to and modifying as previously described by Finore et al., 2014 [19]. All values given are averages of three assays.

A solution of $2.5 \mathrm{mg} \mathrm{mL}^{-1}$ starch in $100 \mathrm{mM}$ sodium acetate buffer with a $\mathrm{pH} 5.6$ was put at $60^{\circ} \mathrm{C}$ under magnetic stirring and incubated with a fixed protein amount of several extracellular enzymatic solutions from different bacteria growth performed with CIN, C4-HSL, and a bacterial growth selected as a reference (blank experiment), as described in Section 2.2.

For each enzymatic digestion, a fixed starch/ total protein weight ratio (substrate/enzyme, $\mathrm{s} / \mathrm{e}$ ) of 25.64 was adopted, which corresponded to $0.79 \mathrm{mg}$ of the total protein for $20 \mathrm{mg}$ of starch substrate. Enzymatic reactions were monitored over the time: aliquots of $0.4 \mathrm{~mL}$ of reaction were withdrawn at $0 \mathrm{~min}, 5 \mathrm{~min}, 10 \mathrm{~min}, 15 \mathrm{~min}, 20 \mathrm{~min}, 30 \mathrm{~min}, 45 \mathrm{~min}$, $1 \mathrm{~h}, 2 \mathrm{~h}, 3 \mathrm{~h}, 4 \mathrm{~h}, 5 \mathrm{~h}, 6 \mathrm{~h}, 7 \mathrm{~h}$, and $24 \mathrm{~h}$; the processes were stopped in an ice-bath for $5 \mathrm{~min}$ and the samples were stored at $-20^{\circ} \mathrm{C}$ overnight. Next, $0.100 \mathrm{~mL}$ of each sample was assayed for the glucose equivalent production (DNS assay). These tests were conducted in 
triplicate and the calibration curve of glucose was elaborated in a concentration interval of $0.05: 1 \mathrm{mg} \mathrm{mL}^{-1}$. Reactions were also monitored by TLC.

One unit of amylase activity was defined as the nanomoles of glucose equivalent which were produced in a minute by $1 \mathrm{mg}$ of the enzymatic solution.

Results were expressed as mean values \pm standard error (ES). Means, ES, calibration curves, and linear regression analyses $\left(R^{2}\right)$ were obtained using Microsoft Excel 2016 (Microsoft Corporation, Redmond, WA, USA).

\section{Results}

The growth of A. amylolyticus cultivated in different conditions was monitored by O.D. $\left(\mathrm{A}_{540 \mathrm{~nm}}\right)$ measurement after $24 \mathrm{~h}$ and the following values were registered: $0.586 \pm 0.015$, blank; $0.558 \pm 0.021,1 \mathrm{CIN} ; 0.560 \pm 0.012,3 \mathrm{CIN}$; and $0.540 \pm 0.019$, C4-HSL $(10 \mu \mathrm{M})$. The O.D. values were supported by the observation at phase-contrast microscopy that showed, after $24 \mathrm{~h}$, similar growth condition (motile and living bacteria) in the blank, $1 \mathrm{CIN}, 3 \mathrm{CIN}$, and C4-HSL. Furthermore, the serial dilution plating method showed non-significative differences between the control and the cultures in presence of CIN and C4-HSL The presence of the QS inhibitor CIN and of C4-HSL standard did not affect the growth of A. amylolyticus.

\subsection{Identification of the Autoinducer}

The ethyl acetate extract ( $100 \mu \mathrm{L}$ of a solution $0.6 \mathrm{mg} \mathrm{mL}^{-1}$ in methanol) of spent medium of A. amylolyticus grown in standard conditions (blank) was analyzed by means of TLC overlay assay, with the biosensor Agrobacterium tumefaciens NTL4 (pCF218; pCF372) able to detect AHLs with medium chain lengths [18] with the aim to assess the presence of signal molecules. A blue spot with an $\mathrm{R}_{\mathrm{f}}$ of 0.4 was detected on the TLC, suggesting the occurrence of AHLs with short acyl chains.

The identification of AHL at the molecular level was performed in the bacterial extract by UPLC-MS/MS analysis monitoring diagnostic MRM transitions associated to HSL standards according to the MS method previously reported, here slightly modified [10]. MS data disclosed the occurrence in the bacterial extract of C4-HSL, as confirmed by both specific MRM transition $172>102$ and Rt $(0.65 \mathrm{~min})$ compared with the standard (Figure 1). A calibration curve built with five calibration points $\left(y=3373.1 \times-328.30 ; R^{2}=0.9997\right)$ was used to assess the absolute amount of the signal metabolite (12 ng) in the whole bacterial culture $(100 \mathrm{~mL})$.

\section{C4-HSL}

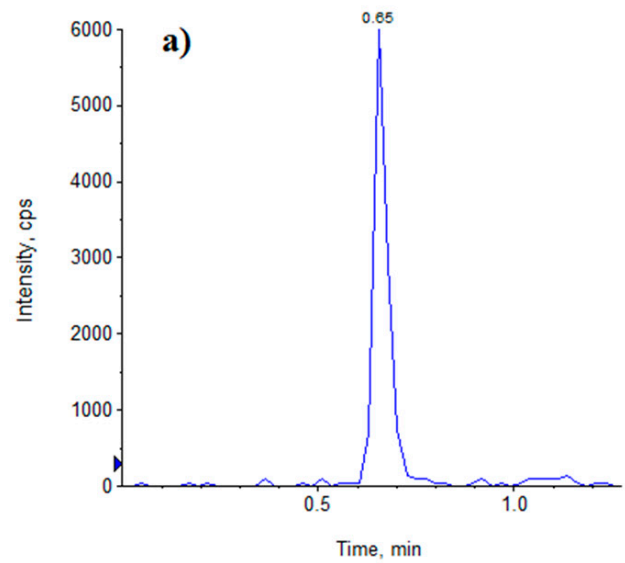

A. amylolyticus extract

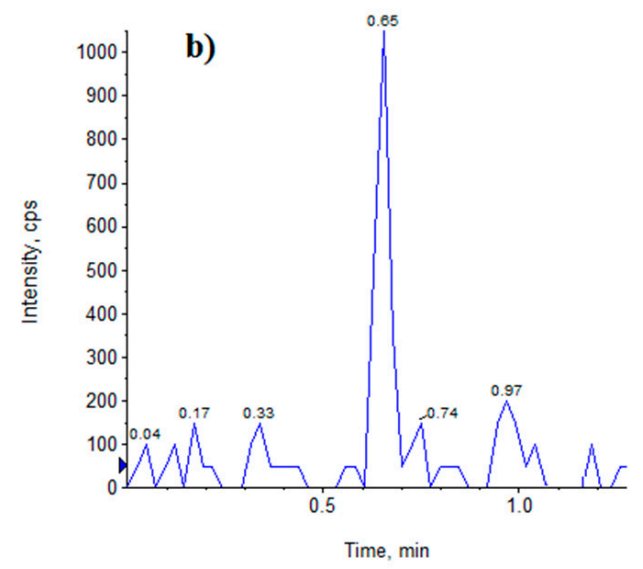

Figure 1. Representative LC-MRM ( $m / z 172>102)$ chromatograms of a) $N$-butanoyl-homoserine lactone (C4-HSL) standard and b) Anoxybacillus amylolyticus extract. 
As regards the extracts of culture with 1 or $3 \mathrm{mg} \mathrm{mL}^{-1}$ of CIN subsequently produced, the addition of this molecule to the culture media induced an appreciable reduction in bacterial culture $(100 \mathrm{~mL})$ of C4-HSL levels measured in the above LC-MS conditions as $6.5 \mathrm{ng}$ and $3.4 \mathrm{ng}$, respectively (Figure 2).

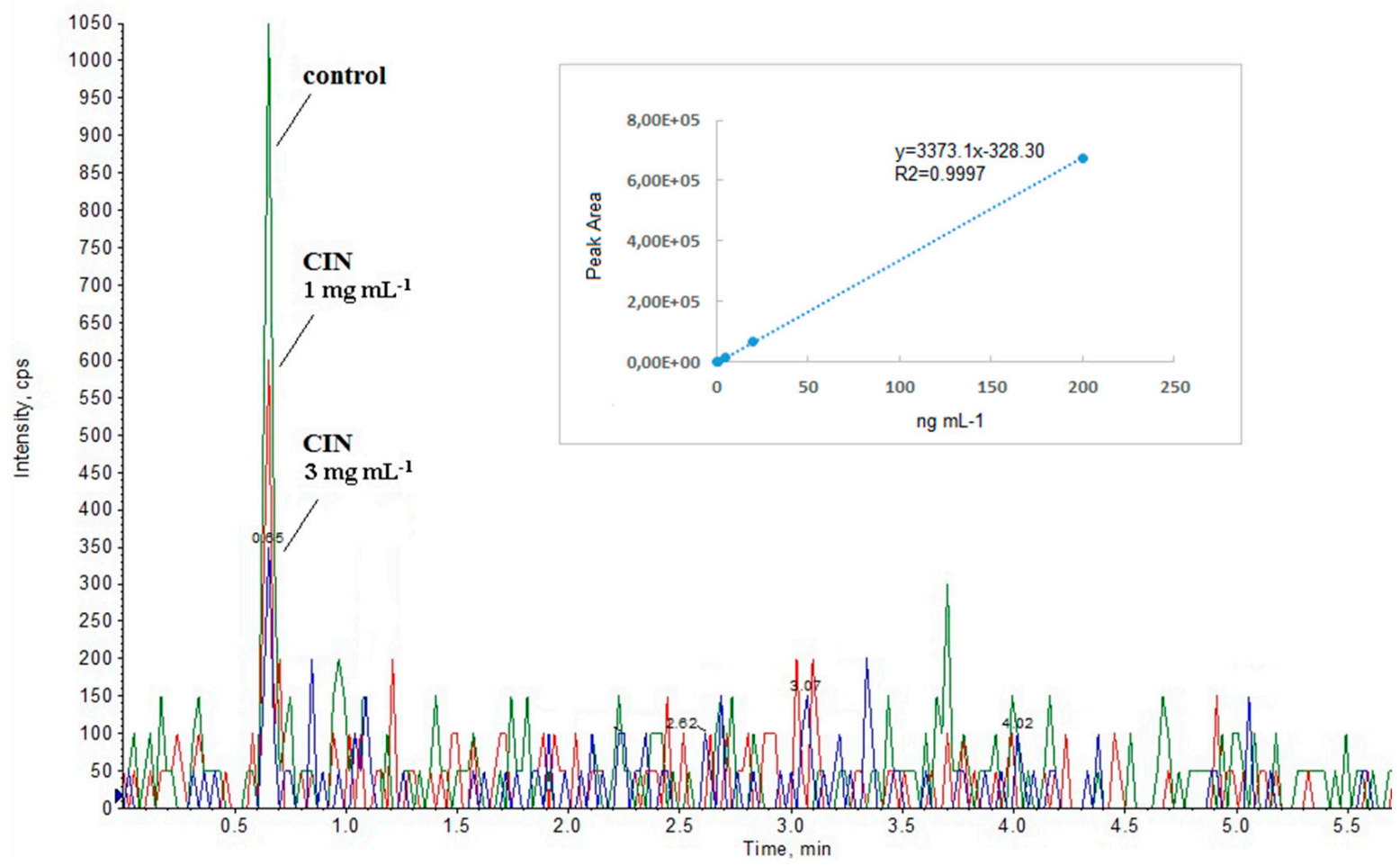

Figure 2. Representative LC- MRM chromatograms for $m / z 172>102$ transition attributed to C4-HSL in the control culture grown in standard conditions (control) and with 1 and $3 \mathrm{mg} \mathrm{mL}^{-1}$ trans-cinnamaldehyde (CIN). The inset shows the calibration curve built by plotting peak area vs standard C4-HSL concentration.

\subsection{A. amylolyticus $\alpha$-amylase Monitoring in Different Bacterial Growth Conditions}

Extracellular $\alpha$-amylase activity was investigated with the aim to evaluate the correlation between the expression of this enzyme and the presence in the growth media of inhibitor molecules or signal molecules of bacterial quorum sensing (QS), such as CIN and C4-HSL, respectively. These compounds were added at different concentrations into the bacterial culture mixtures, as reported in materials and methods. Enzymatic solutions obtained after centrifugation and ultrafiltration were assayed for their total protein content. An evaluation of the total protein amount suggested a possible influence of CIN in the bacterial metabolism with a reduction of the recovered extracellular proteins, although the final concentrations added to the medium were of 7.5 and $22 \mathrm{mM}$ and in general at the limit of those previously reported for other bacteria [19]. In both experiments the concentration of the recovered extracellular protein substantially decreased.

These results would suggest an influence of CIN in bacterial metabolism, but there was no correlation between CIN toxicity and bacterial growth.

All the starch degradation experiments were performed by using the same amount of the extracellular total protein.

In Figure 3, starch digestions with $\alpha$-amylase activity in the enzymatic solutions recovered from bacterial cultures, carried out in presence of C4-HSL and CIN, were compared with the activity expressed in a bacterial culture performed under standard conditions (blank culture). Exogenous C4-HSL and CIN were added to the growth medium at $10 \mu \mathrm{M}$ and $3 \mathrm{mg} \mathrm{mL}^{-1}$, respectively. 


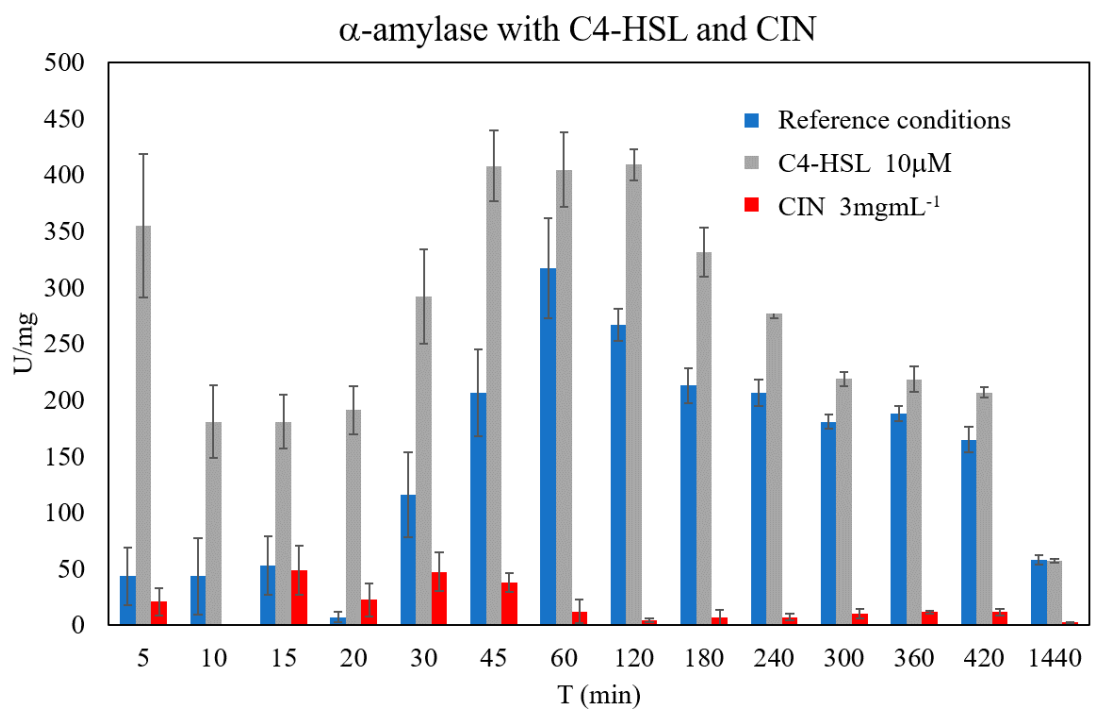

Figure 3. $\alpha$-amylase activity from a culture containing $10 \mu \mathrm{M} \mathrm{C} 4-\mathrm{HSL}$ and CIN $3 \mathrm{mg} \mathrm{mL}^{-1}$, compared with the activity expressed in a bacterial culture performed under standard medium conditions (reference conditions).

This activity was measured in terms of the reduction of the glucose equivalent produced over time (Section 2.5).

In addition, the thin-layer chromatography (TLC) technique was used for monitoring the hydrolytic products of the $\alpha$-amylase enzyme on the starch (Figure S1 of the Supplementary Materials) and the percentage of starch hydrolyzed was calculated (Figure S2 of the Supplementary Materials).

For the experiment with C4-HSL, the enzymatic digestion pattern was similar to that of the experiment under standard conditions; at 45-60 min the maximum enzymatic hydrolytic potential for the production of maltooligosaccharides was recorded, in agreement with the results previously reported by Finore et al. in 2014 [7]. It is important to emphasize that when C4-HSL was present the bacterial medium the $\alpha$-amylase activity appeared to increase (Figure 3). It was evident that at the beginning of the starch digestion (from 5 to $15 \mathrm{~min}$ ) specifically this activity increased by 8 to 4 times: $180.08 \mathrm{U} \mathrm{mg}^{-1}$ at $10 \mathrm{~min}$ in presence of C4-HSL, and $43.62 \mathrm{U} \mathrm{mg}^{-1}$ in the blank conditions at the same time mark. However, this increase was significant up to $4 \mathrm{~h}$ of reaction, when the percentage of hydrolyzed starch was at $47 \%$ for the process with the exogenous C4-HSL and $35 \%$ for the reaction with the $\alpha$-amylase recovered from the standard bacterial growth (Figure S2).

At $24 \mathrm{~h}$, a prevalent accumulation of smaller and less hydrolysable oligosaccharides (end products maltohexaose, maltopentaose, maltotriose, and maltose) (Figure S1), and a physiological enzymatic denaturation could justify a decrease of activity at $57-58 \mathrm{U} \mathrm{mg}^{-1}$ in both enzymatic processes; at this final reaction time, $57 \%$ of the starch was depolymerized in both cases (Figure S2).

Differently, when CIN was added into the bacterial medium, the $\alpha$-amylase activity decreased. The best results were recorded when CIN was used at the highest concentration of $3 \mathrm{mg} \mathrm{mL}^{-1}$, as shown in Figure 3. In this case, the enzymatic activity was remarkably reduced, especially starting from $45-60$ min: resulting in 37.86 and $12.17 \mathrm{U} \mathrm{mg}^{-1}$ at $45 \mathrm{~min}$ and $60 \mathrm{~min}$, respectively, and a minor production of smaller oligosaccharides was observed with only $~ 1 \%$ of the degraded starch (see also Figures S1 and S2). A partial decrease of enzymatic activity was observed also for the experiment with CIN at $1 \mathrm{mg} \mathrm{mL}^{-1}$. Indeed, in this case, in the first $60 \mathrm{~min}$ the trend of enzymatic activity was unusual, and only after $60 \mathrm{~min}$ was the effect was appreciably evident. In fact, at $1 \mathrm{~h}$, a value of $197.05 \mathrm{U} \mathrm{mg}^{-1}$ was measured, which resulted in an appreciably lower value than that obtained under standard conditions ( $317.47 \mathrm{U} \mathrm{mg}^{-1}$ ) and higher than the value with CIN at $3 \mathrm{mg} \mathrm{mL}^{-1}$ (12.17 $\mathrm{U} \mathrm{mg}^{-1}$ ) (Figure S3). These data would suggest a dependence of the $\alpha$-amylase 
activity on the used CIN concentration in the media. It should be noted that this is the first study regarding the possible involvement of CIN on a thermophilic $\alpha$-amylase activity: how enzymatic activity could be modulated by this compound will be investigated in the future, after the purification of the enzymatic protein.

\section{Discussion}

In the search for new biomolecules useful for biotechnological applications, special attention has been paid to extremophilic microorganisms, due to their ability to produce unusual biomolecules (such as thermostable enzymes and exopolysaccharides) as one of their adaptive mechanisms to harsh environmental conditions. Molecules produced under extreme conditions possess features that have proved useful in numerous industrial applications, with the effect of increasing the efficiency and/or the sustainability of production processes [13]. The biosynthesis of many of these biomolecules is regulated by quorum sensing mechanisms through the production, diffusion, and detection of small molecules named autoinducers, mainly represented by AHLs. Since this molecular communication system in extremophiles is still poorly studied, researchers have increasingly focused on this topic. The isolation and identification of AHLs in extremophiles have been reported in halophiles, in particular the genus Halomonas. Some AHLs from H. anticariens FP35(T) were identified: $N$-butanoyl-homoserine lactone (C4-HSL), $N$-hexanoyl-homoserine lactone (C6-HSL), N-octanoyl-homoserine lactone (C8-HSL), and N-dodecanoyl-homoserine lactone (C12-HSL) [20], and their QS systems were composed of the luxR/luxI homologues: hanR (the transcriptional regulator gene) and hanI (the AHL synthase gene) [21]. An AHL with an unsubstituted acyl side chain length of C16 was identified in Halomonas smyrnensis AAD6, a moderately halophilic, exopolysaccharide-producing bacterium isolated from a saltern area in the Aegean region of Turkey The authors hypothesized that the growthphase dependent production of the EPS could be regulated by QS [11,22]. In cultures of the acidophile Acidithiobacillus ferrooxidans, the detection of an AHL with an unsubstituted acyl side chain length of C14 has been reported [23]. In Archaea the presence of a quorum sensing mechanism, based on AHLs and other type of signal molecules, has also been described [10,24-26]. There are few records in the literature on the presence of QS molecules in thermophiles and most of them reported indirect evidences [27-30]. In this paper, we report for the first time the identification of a signal molecule, belonging to the AHLs group, identified as $N$-butanoyl-homoserine lactone (C4-HSL), from cultures of the thermophilic bacterium $A$. amylolyticus. We also assessed the absolute amount of the signal metabolite (12 $\mathrm{ng})$ in the whole bacterial culture $(100 \mathrm{~mL})$, and found it to be very low compared with the common concentrations found in pure cultures of non-extremophiles microorganisms [31]. Since $A$. amylolyticus is able to produce an extracellular amylase enzyme, we investigated the involvement of the QS mechanism in the extracellular amylolytic activity, comparing the C4-HSL level in a control growth, in presence of a QS inhibitor, trans-cinnamaldehyde (CIN) [14], or of exogenous C4-HSL.

In effect, the presence of the QS inhibitor CIN in the medium decreased the synthesis of the autoinducer C4-HSL, as revealed by LC-MS analysis, and suggested its possible involvement in amylolytic activity; conversely, the presence of extra C4-HSL resulted in an appreciable increase of extracellular amylase activity. However, QS may affect other protein(s) and its impact on $\alpha$-amylase activity could be indirect, resulting from the assay being based on a fixed amount of extracellular protein.

The regulatory link between QS signals and extracellular biomolecules (enzymes, exopolysaccharides, and virulence factors) production is a possible target to mitigate the virulence of pathogens, such as Pseudomonas aeruginosa, and for enhancing the production of attractive and valuable molecules [32,33]. Our results showed that the production of $\alpha$-amylase by $A$. amylolyticus could be regulated by a quorum sensing mechanism based on AHLs, and that it could be increased by the supplementation of C4-HSL in the growth medium. In fact, under the latter growth conditions, we noted an increase in $\alpha$-amylase activity of up to $50 \%$ in the first $45 \mathrm{~min}$ of the starch digestion processes, with respect to 
the standard growth conditions. This result is particularly significant because $\alpha$-amylase produced by the thermophilic $A$. amylolyticus represents a thermostable enzyme able to digest cellulose, hemicellulose, and starch at high temperatures, working conditions that are often present in industrial processes.

\section{Conclusions}

In conclusion, our results provide direct evidence of AHL production in thermophilic microorganisms, which could be responsible for a communication system. In particular, by using highly sensitive mass spectrometry-based approaches, we identified in A. amylolyticus C4-HSL as autoinducer $[11,34]$. Moreover, biochemical studies highlighted the correlation of C4-HSL levels with the extracellular amylolytic activity of A. amylolyticus. Overall, our data suggest the occurrence of a metabolic network including a QS mechanism and glycosidase activities, and the regulation of QS as a possible strategy to implement the sustainable production of valuable biomolecules in different industrial sectors.

Supplementary Materials: The following are available online at https:/ /www.mdpi.com/article/ 10.3390/microorganisms9040819/s1, Figure S1: TLC analysis of starch digestion at 1 and $24 \mathrm{~h}$, Figure S2: \% of starch hydrolysis by using $\alpha$-amylases from bacterial growth in standard condition, with CIN $\left(3 \mathrm{mgmL}^{-1}\right)$ and C4-HSL $(10 \mu \mathrm{M})$, Fugure S3: $\alpha$-Amylase activity from a culture containing $1 \mathrm{mg} \mathrm{mL}^{-1}$ of CIN.

Author Contributions: Conceptualization, A.T. and G.T.; methodology, G.T., A.C., A.T., A.P., and I.F.; formal analysis, A.I. and I.F.; investigation, A.T., A.C., I.F., and A.I.; data curation, A.T., A.C., and A.P.; writing-original draft preparation, A.T., A.C., A.P., and G.T.; writing-review and editing, A.T., A.C., and G.T.; supervision, G.T. All authors have read and agreed to the published version of the manuscript.

Funding: This research received no external funding.

Institutional Review Board Statement: Not applicable.

Informed Consent Statement: Not applicable.

Data Availability Statement: The data presented in this study are available on request from the corresponding author.

Acknowledgments: The authors are grateful to Carmine Iodice for his helpful and valuable technical assistance.

Conflicts of Interest: The authors declare no conflict of interest.

\section{References}

1. Poli, A.; Esposito, E.; Lama, L.; Orlando, P.; Nicolaus, G.; de Appolonia, F.; Gambacorta, A.; Nicolaus, B. Anoxybacillus amylolyticus sp. nov., a thermophilic amylase producing bacterium isolated from Mount Rittmann (Antarctica). Syst. Appl. Microbiol. 2006, 29, 300-307. [CrossRef] [PubMed]

2. Abdel-Fattah, Y.R.; Soliman, N.A.; El-Toukhy, N.M.; El-Gendi, H.; Ahmed, R.S. Production, purification and characterization of thermostable $\alpha$-amylase produced by Bacillus licheniformis isolate AI20. J. Chem. 2013, 673173. [CrossRef]

3. Asgher, M.; Asad, M.J.; Rahman, S.U.; Legge, R.L. A thermostable $\alpha$-amylase from a moderately thermophilic Bacillus subtilis strain for starch processing. J. Food Eng. 2007, 79, 950-955. [CrossRef]

4. Annamalai, N.; Thavasi, R.; Vijayalakshmi, S.; Balasubramanian, T. Extraction, purification and characterization of thermostable, alkaline tolerant $\alpha$-amylase from Bacillus cereus. Indian J. Microbiol. 2011, 51, 424-429. [CrossRef] [PubMed]

5. Mehta, D.; Satyanarayana, T. Bacterial and Archaeal $\alpha$-Amylases: Diversity and Amelioration of the Desirable Characteristics for Industrial Applications. Front. Microbiol. 2016, 7, 1-21. [CrossRef]

6. Pandey, A.; Nigam, P.; Soccol, C.R.; Soccol, V.T.; Sing, D.; Mohan, R. Advances in microbial amylases. Biotechnol. Appl. Biochem. 2000, 31, 135-152. [CrossRef]

7. Finore, I.; Di Donato, P.; Poli, A.; Kirdar, B.; Kasavi, C.; Toksoy Oner, E.; Nicolaus, B.; Lama, L. Use of Agro Waste Biomass for $\alpha$-Amylase Production by Anoxybacillus amylolyticus: Purification and Properties. J. Microb. Biochem. Technol. 2014, 6, 320-326.

8. Williams, P. Quorum Sensing, communication and cross-kingdom signalling in the bacterial world. Microbiology 2007, 153, 3923-3938. [CrossRef]

9. Abbamondi, G.R.; De Rosa, S.; Iodice, C.; Tommonaro, G. Cyclic dipeptides produced by marine sponge-associated bacteria as Quorum Sensing signals. Nat. Prod. Commun. 2014, 9, 229-232. [CrossRef] 
10. Tommonaro, G.; Abbamondi, G.R.; Iodice, C.; Tait, K.; De Rosa, S. Diketopiperazines produced by the halophilic archaeon, Haloterrigena hispanica, activate AHL bioreporters. Microb. Ecol. 2012, 63, 490-495. [CrossRef]

11. Abbamondi, G.R.; Suner, S.; Cutignano, A.; Grauso, L.; Nicolaus, B.; Toksoy Oner, E.; Tommonaro, G. Identification of N-Hexadecanoyl-L-homoserine lactone (C16-AHL) as signal molecule in halophilic bacterium Halomonas smyrnensis AAD6. Ann. Microbiol. 2016, 66, 1329-1333. [CrossRef]

12. Tommonaro, G.; Abbamondi, G.R.; Toksoy Oner, E.; Nicolaus, B. Investigating the Quorum Sensing system in halophilic bacteria. In Halophiles: Biodiversity and Sustainable Exploitation; Maheshwari, D.K., Saraf, M., Eds.; Springer International Publishing: Cham, Switzerland, 2015; pp. 189-207.

13. Finore, I.; Lama, L.; Poli, A.; Di Donato, P.; Nicolaus, B. Biotechnology implications of extremophiles as life pioneers and wellspring of valuable biomolecules. In Microbial Factories: Biodiversity, Biopolymers, Bioactive Molecules; Kalia, V.C., Ed.; Springer: New Delhi, India, 2015; Volume 2, pp. 193-216.

14. Chang, C.Y.; Krishnan, T.; Wang, H.; Chen, Y.; Yin, W.F.; Chong, Y.M.; Tan, L.Y.; Chong, T.M.; Chan, K.G. Non-antibiotic quorum sensing inhibitors acting against $\mathrm{N}$-acyl homoserine lactone synthase as druggable target. Sci. Rep. 2014, 4, 1-8. [CrossRef]

15. Bradford, M.M. A rapid and sensitive method for the quantitation of microgram quantities of protein utilizing the principle of protein-dye binding. Anal. Biochem. 1976, 72, 248-254. [CrossRef]

16. Bernfeld, P. Amylases $\alpha$ and $\beta$. In Methods in Enzymology; Kaplan, N., Colowick, S., Eds.; Academic Press: New York, NY, USA, 1955; Volume 1, pp. 149-158.

17. Tempé, J.; Petit, A.; Holsters, M.; van Montagu, M.; Schell, J. Thermosensitive step associated with transfer of the Ti plasmid during conjugation: Possible relation to transformation in crown gall. PNAS 1977, 74, 2848-2849. [CrossRef]

18. Fuqua, C.; Winans, S.C. Conserved cis-acting promoter elements are required for density-dependent transcription of Agrobacterium tumefaciens conjugal transfer genes. J. Bacteriol. 1996, 178, 435-440. [CrossRef]

19. Malheiro, J.F.; Maillard, J.-Y.; Borges, F.; Simões, M. Evaluation of cinnamaldehyde and cinnamic acid derivatives in microbial growth control. Int. Biodeterior. Biodegrad. 2019, 141, 71-78. [CrossRef]

20. Llamas, I.; Quesada, E.; Martínez-Cánovas, M.J.; Gronquist, M.; Eberhard, A.; González, J.E. Quorum Sensing in halophilic bacteria: Detection of N-acyl-homoserine lactones in the exopolysaccharide-producing species of Halomonas. Extremophiles 2005, 9, 333-341. [CrossRef]

21. Tahrioui, A.; Quesada, E.; Llamas, I. The hanR/hanI quorum-sensing system of Halomonas anticariensis, a moderately halophilic bacterium. Microbiology 2011, 157, 3378-3387. [CrossRef]

22. Poli, A.; Nicolaus, B.; Denizci, A.A.; Yavuzturk, B.; Kazan, D. Halomonas smyrnensis sp. nov., a moderately halophilic, exopolysaccharide-producing bacterium. Int. J. Syst. Evol. Microbiol. 2013, 63, 10-18. [CrossRef]

23. Rivas, M.; Seeger, M.; Jedlicki, E.; Holmes, D.S. Second acyl homoserine lactone production system in the extreme acidophile Acidithiobacillus ferrooxidans. Appl. Environ. Microbiol. 2007, 73, 3225-3231. [CrossRef]

24. Paggi, R.A.; Martone, C.B.; Fuqua, C.; De Castro, R.E. Detection of Quorum Sensing signals in the haloalkaliphilic archaeon Natronococcus occultus. FEMS Microbiol. Lett. 2003, 221, 49-52. [CrossRef]

25. Zhang, G.; Zhang, F.; Ding, G.; Li, J.; Guo, X.; Zhu, J.; Zhou, L.; Cai, S.; Liu, X.; Luo, Y.; et al. Acyl homoserine lactone-based Quorum Sensing in a methanogenic archaeon. ISME J. 2012, 6, 1336-1344. [CrossRef] [PubMed]

26. Megaw, J.; Gilmore, B.F. Archaeal persisters: Persister cell formation as a stress response in Haloferax volcanii. Front. Microbiol. 2017, 8, 1-10. [CrossRef] [PubMed]

27. Johnson, M.R.; Montero, C.I.; Conners, S.B.; Shockley, K.R.; Bridger, S.L.; Kelly, R.M. Population density-dependent regulation of exopolysaccharide formation in the hyperthermophilic bacterium Thermotoga maritima. Mol. Microbiol. 2005, 55, 664-674. [CrossRef] [PubMed]

28. Nichols, J.D.; Johnson, M.R.; Chou, C.-J.; Kelly, R.M. Temperature, not LuxS, mediates AI-2 formation in hydrothermal habitats. FEMS Microbiol. Ecol. 2009, 68, 173-181. [CrossRef]

29. Shulami, S.; Shenker, O.; Langut, Y.; Lavid, N.; Gat, O.; Zaide, G.; Zehavi, A.; Sonenshein, A.L.; Shoham, Y. Multiple regulatory mechanisms control the expression of the Geobacillus stearothermophilus gene for extracellular xylanase. J. Biol. Chem. 2014, 289, 25957-25975. [CrossRef]

30. Pérez-Rodríguez, I.; Bolognini, M.; Ricci, J.; Bini, E.; Vetriani, C. From deep-sea volcanoes to human pathogens: A conserved quorum-sensing signal in Epsilon proteobacteria. ISME J. 2015, 9, 1222-1234. [CrossRef]

31. Hu, H.; He, J.; Liu, J.; Yu, H.; Tang, J.; Zhang, J. Role of N-acyl-homoserine lactone (AHL) based quorum sensing on biofilm formation on packing media in wastewater treatment process. RSC Adv. 2016, 6, 11128. [CrossRef]

32. Basaran, T.I.; Berber, D.; Gökalsın, B.; Tramice, A.; Tommonaro, G.; Abbamondi, G.R.; Erginer Hasköylü, M.; Toksoy Öner, E.; Iodice, C.; Sesal, N.C. Extremophilic Natrinema versiforme against Pseudomonas aeruginosa Quorum Sensing and Biofilm. Front. Microbiol. 2020, 11, 1-10. [CrossRef]

33. Abbamondi, G.R.; Kambourova, M.; Poli, A.; Finore, I.; Nicolaus, B. Quorum Sensing in Extremophiles. In Quorum Sensing; Tommonaro, G., Ed.; Academic Press: Cambridge, MA, USA, 2019; Volume 4, pp. 97-123.

34. Cutignano, A. Analytical Approaches for the Identification of Quorum Sensing Molecules. In Quorum Sensing; Tommonaro, G., Ed.; Academic Press: Cambridge, MA, USA, 2019; Volume 2, pp. 29-53. 